\title{
About the reasons for the rare plant species disappearance in the Upper Volga region
}

\author{
Elena Borisova ${ }^{1}$, Nikita Konotop $^{1}$, Julia Vinogradova ${ }^{1}$, Dmitriy Markov ${ }^{1}$, and Alexey \\ Sivukhin ${ }^{1}$ \\ ${ }^{1}$ Ivanovo State University, Ivanovo, 153025, Russia
}

\begin{abstract}
The problems of the extinction of aquatic plant species in Ivanovo region glacial lakes are discussed. As a result of research a sharp decrease in the number of rare hydrophytes (Elatine hydropiper, Isoetes lacustris, I. echinospora, Sparganium gramineum) has been established. The reasons are complex, they are associated with the eutrophication of ponds, heavy metals soil pollution, uncontrolled recreational loads and Elodea canadensis invaded into lake ecosystems. The ecological niche of Sparganium gramineum in the lakes is occupied by $S . \times$ longifolium, the hybridogenic origin of which is proved by modern molecular genetic analysis.
\end{abstract}

\section{Introduction}

In the Upper Volga region the ways to preserve natural biodiversity and the natural functioning of natural systems are very relevant. Due to increasing anthropogenic pressures and pollution of natural communities rare plants species are the most vulnerable. Every year there is decrease of their populations, areas of distribution, eviction of indigenous species by invasive ones. The Red Book of the Ivanovo Region includes 149 species of vascular plants, including 12 aquatic species - hydrophytes [1]. In recent decades some aquatic species associated with glacial lakes (Elatine hydropiper, Isoetes lacustris, I. echinospora, Potamogeton praelongus, Sparganium gramineum, etc.) have been endangered. Similar problems are observed in other regions. The rare species Sparganium gramineum is replaced by a stable hybrid of $S$. $\times$ longifolium by the lakes eutrophication [2-3]. Everywhere there is a displacement of invasive species by invasive ones $[1,4]$.

In the Ivanovo region, all glacial lakes are protected and have a status of specially protected natural areas. As part of a comprehensive environmental survey of the Valdayskoe and Vysokovskoe lakes, the reasons for the reduction in the number of rare hydrophytes were studied. This problem especially concern the rare glacial species (S. gramineum), which is decreasing in number from year to year and disappears completely [1-3,5].

The purpose of this study was to conduct comprehensive monitoring of the glacial lakes Valdayskoe and Vysokovskoe with the habitat of rare hydrophytes and determine the causes of their disappearance. 


\section{Materials and methods}

Studies were conducted in the Ivanovo region, Ivanovo district, in the vicinity of a large city - Ivanovo. Glacial lakes Valdayskoe and Vysokovskoe have been researched. Water analysis was carried out and soil samples were taken in the surroundings of these lakes.

Analysis of soil samples was carried Hby standard method [6]. Laboratory preparation of extracts from soil samples was carried out on the biological and chemical faculty of Ivanovo State University basis, the Hardware analysis - with 210 VGP atomic absorption spectrophotometer.

Water samples were taken in the lakes Valdayskoe and Vysokovskoe in 2018. Organoleptic and chemical analyses of water were performed in a specialized laboratory of the branch of the Federal State Health Institution in the city of Shuya, analysis of the content of heavy metals in water was performed in the laboratory of geographic information technologies using a PE-5300VI spectrophotometer [7].

The hybrids were detected at the Institute for Biology of Inland Waters RAS Laboratory of Geography and Systematics of Aquatic Plants; morphological and molecular genetic studies of S. gramineum from Valdayskoe and Vysokovskoe lakes were carried out. Standard molecular techniques were performed: DNA isolation, PCR, and sequencing [8]. Polymerase chain reaction - ISSR method (Inter simple sequence repeats) [9]. The material for analysis was samples of leaf tissue. DNA was isolated by the sorbent method with some modifications [10].

\section{Results and discussion}

Lake Valdayskoe is located in the north-east $3 \mathrm{~km}$ of Ivanovo near the Sergievskoe and Byakovo villages. The lake is small (the area -27.1 ha, the maximum depth $-13 \mathrm{~m}$ ) and closed. In the 1920s Valdayskoe Lake and its coastal zone been studied in detail [11]. Large populations of Isoëtes echinospora were noted, the plants were found almost along the entire perimeter of the lake and in some places formed large groups. Sparganium gramineum formed a continuous ring 3-16 m wide at a depth of 140-240 cm, in association with Ceratophyllum demersum.

Lake Vysokovskoe is located in $12 \mathrm{~km}$ north of the city of Ivanovo near the village of Vysokovo (the area - 36.4 ha, the maximum depth - $10 \mathrm{~m}$ ). In the 1920-1980s Isoëtes lacustris was noted in the lake. Sparganium gramineum formed small loose groups within an area of $20-80 \mathrm{~m}$.

In 2012-2019 the flora of the lakes sharp decrease in the number of Isoetes echinospora in Valdayskoe Lake was noted. It is found in solitary specimens, superseded by Elodea canadensis. Isoëtes lacustris in Lake Vysokovskoe was not found, it might have disappeared.

Sparganium gramineum specimens were observed annually in the lakes during the studies, but morphologically they differ from the typical Sparganium gramineum with keeled leaves and with rising inflorescences [5]. Therefore, molecular genetic studies were performed to obtain amino acid sequences using the ITS marker to identify polymorphic positions that distinguish hybrids well [8]. The result of molecular genetic analysis (polymorphic positions) is presented in Table 1. An analysis of the results on the ITS nuclear marker revealed that $S$. gramineum from Lake Valdayskoe is a hybrid of $S$. $\times$ longifolium. About 12 polymorphic positions were found. Molecular genetic studies of plants from Lake Vysokovskoe have not been conducted. 
Table 1. Polymorphic positions of $S . \times$ longifolium from Lake Valdayskoe by ITS marker.

\begin{tabular}{|c|c|c|c|c|c|c|c|c|c|c|c|c|}
\hline \multirow{2}{*}{$\begin{array}{c}\text { Sample } \\
\text { number }\end{array}$} & \multicolumn{10}{|c|}{ The location of polymorphic positions in the gene } \\
\cline { 2 - 15 } & 20 & 33 & 39 & 45 & 85 & 87 & 91 & 16 & 383 & 388 & 405 & 451 \\
\hline NK9 & Y & K & Y & Y & Y & Y & R & N & Y & Y & Y & Y \\
\hline NK10 & Y & K & Y & Y & Y & Y & R & N & Y & Y & Y & Y \\
\hline NK11 & C & T & T & C & T & Y & A & T & Y & Y & Y & Y \\
\hline NK12 & C & T & T & C & T & Y & A & Y & Y & Y & Y & T \\
\hline
\end{tabular}

*Note: $G+T=K, T+C=Y, G+A=R, A+T=W, N=3,4 A N Y$

Being in close proximity to the regional center, the lakes are places of mass summer recreation for people. On the shores of the lake daily in the summer, there are more than 5070 cars. Most cars stop near the water's edge, spontaneous picnic spots, tent camps are organized, household rubbish is left. This leads to soil pollution in these lakes. When analyzing soils in the vicinity of the investigated lakes, excesses of the maximum permissible concentration) of some heavy metals were found (Table 2.) There are almost 5 times more mobile forms of cobalt in the soils near Lake Valdayskoe than in the soils of the lake near Vysokovskoe. The content of nickel in the soil is exceeded in the soils by Lake Valdayskoe by $20 \%$, by almost $50 \%$ by Lake Vysokovskoe.

Table 2. The content of heavy metals in soil samples.

\begin{tabular}{|l|l|l|l|l|l|l|l|c|}
\hline \multirow{2}{*}{ Lake name } & \multicolumn{10}{|c|}{ The metal content in $\mathrm{mg} / \mathrm{kg}$} \\
\cline { 2 - 9 } & $\mathbf{C u}$ & \multicolumn{1}{|c|}{$\mathbf{Z n}$} & $\mathbf{N i}$ & \multicolumn{1}{|c|}{$\mathbf{C o}$} & $\mathbf{P b}$ & \multicolumn{1}{|c|}{$\mathbf{~} \mathbf{M n}$} & $\mathbf{C d}$ \\
\hline Valdayskoye & $4,23^{* /}$ & $18,60 /$ & $7,51 /$ & $8,32 /$ & $2,43 /$ & $5321 /$ & $130,1 /$ & 0,704 \\
& $6,60^{* *}$ & 29,90 & 5,11 & 11,30 & 2,89 & 78,90 & 73,70 & \\
\hline Vysokovskoye & $5,21 /$ & $55,38 /$ & $13,70 /$ & $24,04 /$ & $5,75 /$ & $3777,2 /$ & $218,34 /$ & 0,676 \\
& 3,53 & 30,38 & 11,22 & 26,91 & 2,86 & 69,30 & 88,90 & \\
\hline
\end{tabular}

* Note: *gross forms, **movable forms

Heavy metals salts from soils fall into lakes and plants actively absorb some heavy metals (lead and cadmium) from the soil and from water and accumulate them.

When studying the composition of water in lakes in 1920. Extreme poverty of the salt regime was observed, as well as high transparency up to 7-9 $\mathrm{m} \mathrm{[12].} \mathrm{The} \mathrm{results} \mathrm{of} \mathrm{analyzes}$ of water samples in lakes made in 2018 are presented in Table 3.

Analyzing the data of chemical indicators of water in the lakes, it was found that the composition of the water changed and salts of nitric and nitrous acids appeared in it, because the lake is used for swimming. Constant presence of nitrites and phosphates in the water is not observed. Transparency has decreased and amounts to $1.5-1.8 \mathrm{~m}$ in the summer months.

Despite the fact that the lakes are specially protected natural areas, protection regimes are constantly violated and not controlled. Therefore, ecosystems of lakes are disturbed, water and soil are polluted. As a result of anthropogenic changes and degradation of coastal vegetation in the studied lakes, the number of rare vulnerable plant species has sharply decreased. Sparganium gramineum is superseded by a more adapted hybrid of $S$. $\times$ longifolium. Glacial relics of Isoëtes lacustris, I. echinospora almost disappeared in these lakes due to the spread of the invasive species - Elodea canadensis. Elatine hydropiper is sporadically noted into the Valdayskoe Lake. 
Table 3. The amount of dissolved substances in the water of the lakes.

\begin{tabular}{|c|c|c|c|}
\hline \multirow[b]{2}{*}{ Indicators(Units) } & \multicolumn{2}{|c|}{ Value } & \multirow[b]{2}{*}{$\begin{array}{l}\text { Hygienic } \\
\text { standard }\end{array}$} \\
\hline & $\begin{array}{l}\text { Valdayskoe } \\
\text { Lake }\end{array}$ & $\begin{array}{c}\text { Vysokovskoe } \\
\text { Lake }\end{array}$ & \\
\hline \multicolumn{4}{|c|}{ Organoleptic indicators: } \\
\hline Smell at $20^{\circ} \mathrm{C}$ (point) & 1 & 2 & $\leq 2$ \\
\hline Smell at $60^{\circ} \mathrm{C}$ (point) & 2 & 2 & $\leq 2$ \\
\hline $\mathrm{pH}$ & 7,2 & 6,8 & $6,5 \div 8,5$ \\
\hline Turbidity & 0,96 & 0,98 & $\leq 20$ \\
\hline Color (grad) & 18,1 & 20,6 & $\leq 35$ \\
\hline Dry residue $\left(\mathrm{mg} / \mathrm{dm}^{3}\right)$ & 175,8 & 194,1 & $\leq 1000$ \\
\hline Total hardness & 3,1 & 3,4 & $\leq 7,0$ \\
\hline Permanganate oxidation $\left(\mathrm{mg} / \mathrm{dm}^{3}\right)$ & 4,0 & 3,9 & $\leq 7,0$ \\
\hline Petroleum products in total $\left(\mathrm{mg} / \mathrm{dm}^{3}\right)$ & $<0,1$ & $<0,1$ & $\leq 0,3$ \\
\hline Surfactant $\left(\mathrm{mg} / \mathrm{dm}^{3}\right)$ & $<0,01$ & $<0,01$ & $\leq 0,5$ \\
\hline Phenolic index $\left(\mathrm{mg} / \mathrm{dm}^{3}\right)$ & - & - & $\leq 0,25$ \\
\hline Dissolved oxygen $\left(\mathrm{mg} / \mathrm{dm}^{3}\right)$ & 5,4 & 5,7 & $\geq 4,0$ \\
\hline \multicolumn{4}{|c|}{ Chemical composition of water: } \\
\hline NH3 $\left(\mathrm{mg} / \mathrm{dm}^{3}\right)$ & 0,05 & 0,1 & $\leq 1,5$ \\
\hline $\mathrm{Fe}\left(\mathrm{mg} / \mathrm{dm}^{3}\right)$ & 0,32 & 0,47 & $\leq 1,0$ \\
\hline $\mathrm{Cu}\left(\mathrm{mg} / \mathrm{dm}^{3}\right)$ & 0,0014 & 0,005 & $\leq 1,0$ \\
\hline $\mathrm{Mn}\left(\mathrm{mg} / \mathrm{dm}^{3}\right)$ & 0,05 & 0,05 & $\leq 0,1$ \\
\hline Nitrates $\left(\mathrm{mg} / \mathrm{dm}^{3}\right)$ & 0,17 & 0,68 & $\leq 45,0$ \\
\hline Nitrite $\left(\mathrm{mg} / \mathrm{dm}^{3}\right)$ & 0,07 & 0,08 & $\leq 3,3$ \\
\hline $\mathrm{Pb}\left(\mathrm{mg} / \mathrm{dm}^{3}\right)$ & 0,0004 & 0,0006 & $\leq 0,01$ \\
\hline Sulphates $\left(\mathrm{mg} / \mathrm{dm}^{3}\right)$ & 33,4 & 24,6 & $\leq 500$ \\
\hline Chlorides $\left(\mathrm{mg} / \mathrm{dm}^{3}\right)$ & 6,4 & 6,9 & $\leq 350$ \\
\hline Fluorides $\left(\mathrm{mg} / \mathrm{dm}^{3}\right)$ & 0,17 & 0,11 & $\leq 1,5$ \\
\hline $\mathrm{Zn}\left(\mathrm{mg} / \mathrm{dm}^{3}\right)$ & 0,013 & 0,018 & $\leq 1,0$ \\
\hline
\end{tabular}

To preserve the data of the unique lakes of the Upper Volga region and the rare species in them, strict control of compliance with protection regimes, organizational regulation of recreational loads, environmental monitoring of water, soils, and populations of rare species is necessary. It is advisable to allocate special areas - the reserves with a special protection regime will be established prohibiting any anthropogenic interference.

\section{Conclusion}

As a result of research in the glacial lakes of Valdayskoe and Vysokovskoe a sharp decrease in the number of rare hydrophytes (Elatine hydropiper, Isoëtes lacustris, I. echinospora, Sparganium gramineum) has been found. The reasons for these processes are complex.

Based on a comparison of the main indicators of water composition in the lakes, the presence of nitrates and phosphates, turbidity of the water and a sharp decrease in transparency are shown. Soils in the vicinity of the lakes are contaminated with heavy metals, lead, manganese and copper are also present in the water of the studied lakes. This is due to the eutrophication of water bodies, soil pollution with heavy metals, uncontrolled recreational loads. The negative effect on rare species distribution is caused by large groups of Elodea canadensis, displacing Isoëtes lacustris, I. echinospora, Elatine hydropiper. 
The ecological niche of Sparganium gramineum in the lakes is occupied by $S$. $\times$ longifolium, whose hybridogenic origin has been confirmed by molecular-genetic analyses. Ecological monitoring of the water composition, the state of rare species populations in the lakes and control of the protection regimes of these unique lakes are thought necessary.

\section{References}

1. Krasnaya Kniga Ivanovskoy oblasti. Ivanovo: IPK «PresSto», 2 (2010)

2. A. A. Bobrov, O. A. Mochalova, E. V. Chemeris. Botanicheskiy jurnal, 99(9), 10251043 (2014)

3. N. K. Konotop, J. S. Vinogradova. Problemy botaniki: istoriya i sovremennost. Pod red. V.A. Agafonova. Voronezh: Tsifrovaya poligrafiya, 391, (2020)

4. E. A. Borisova. Rus. Jur. of Biolog. Invasions, 2(1), 1-5 (2011)

5. C. D. K. Cook, M. S. Nicholls. Botanica Helvetica, 96(2), 213-267 (1986)

6. S. A. Barry and S. C. Clark. New Phyto, 81, 773-783 (1978)

7. N. V. Yakovenko, D. S. Markov, E. P. Turkina. Ecology, Environment and Conservation Paper, 21, 111-119 (2015)

8. J. D. Sulman, B.T. Drew, C. Drummond, E. Hayasaka, K. J. Sytsma. American Journal of Botany, 100(10), 2023-2039 (2013)

9. E. Zietkiewicz, A. Rafalski, D. Labuda. Genome fingerprinting by simple sequence repeat (SSR)-anchored polymerase chain reaction amplification. Genomics, 20, 176183 (1994)

10. M. Höss, S. Pääbo, Nucleric Acid Research, 21, 3913-3914 (1993)

11. N. V. Corde, D. A.Lastochkin Д.A. Valdayskoye ozero. Ocherk naseleniya ozera i yego gidrologicheskaya kharakteristika Ivanovo-Voznesensk, 129 (1930)

12. A. N. Sivukhin, D.S. Markov, E. A. Borisova. Problems of regional ecology, 3, 81-87 (2019) 